\title{
Home, James, and don't spare the horses: The inevitability of a second Sydney casino
}

ABSTRACT: Casinos have become an important yet controversial element of many contemporary metropoles, with cities on the Pacific Rim no exception. Twenty years after the opening of Sydney's first casino, construction of its second is currently underway on a contentious site, the Barangaroo precinct. This paper offers a historical analysis of the current casino project against the backdrop of casino development in Aastrabia general, comparing the current project to the development of Sydney's first casino, The Star formerly Star City). We argue that both have been predicated on a cosmopolitan gaze contributing to the image of a 'global city' and the promise of increased tax revenues. As a result, planning processes have lacked legitimacy, particularly in the case of Crown, which involves the use of significant pubfic assets. This paper critiques the spectacle of iconic developments of both The Star at Pyrmont and Crown Casino at Barangaroo when set against the morphology and urban form, suggesting that a more sincergengagement with the specificity of place on major developments would mitigate against the polarising effects of ontested urban projects.

Keywords: Barangaroo; casino development; privatisation of public space; Sydney global

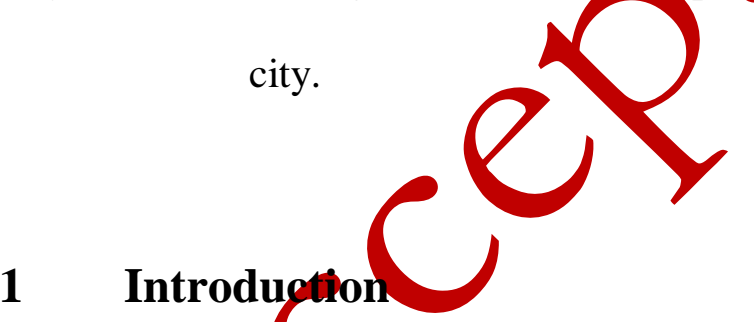

The controversy of the Barangaroo development in Sydney, New South Wales (NSW) has thus far put the \&potlight on the successive Liberal-National Coalition state governments that prima facie have granted carte blanche to Lendlease, the Sydney-based multinational corporation that in 2009 was selected by the Barangaroo Delivery Authority (BDA) to develop the Barangaroo South precinct (BDA 2013; Lendlease n.d.a.; n.d.b.). ${ }^{1}$ Mike Baird,

\footnotetext{
${ }^{1}$ The Barangaroo Delivery Authority (BDA) is a statutory corporation of the NSW state parliament and was created by the Barangaroo Delivery Authority Act 2009. The BDA is responsible to the Premier of NSW (NSW Government 2009).
} 
the recently retired ${ }^{2}$ NSW State Premier, followed from his predecessor Barry O'Farrell ${ }^{3}$ in continuing this trajectory. On 26 November 2015 the [then] Premier Baird allowed further height and floor space increases (McKenny and Saulwick 2015), the latter of which had previously been doubled from the time of first submission. The potential for a casino within the Barangaroo development was first put forward in 2009 in an unsolicited proposal to the NSW Government (Chew 2015). Commenting at the time, the [then] Premier O'Farrell stated of the proposal by James Packer, then Chair of Crown:

He's put a proposal forward that is unique ... that would see a six-star hote - something this city doesn't have - located at Barangaroo and yes, part of that proposal roller's room ... This will be a VIP-only facility ... there will be no poker hachines (O'Farrell, in $\mathrm{ABC} 2017 \mathrm{a})$

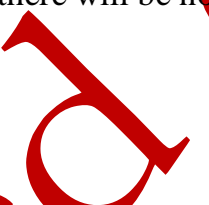

Planning approval for the concept plan was gafted for the eighth modification (MOD8) in June 2016 (Department of Planning 2016)

The Barangaroo development has prompted critical observations from Pham (2015) and Johnston and Clegg (2012), be former concerned with the social impact of its built form, the latter examining the effect uppn public management of the placement of Sydney as a 'global city'. These studies form part of a larger emerging body of work on Australian gambling and its ventes 6 ivingstone 2005; Markham, Doran, and Young 2014) in Macau (Simpson 2014; Schneider 2015) and Singapore (Henderson 2012).

\footnotetext{
${ }^{2}$ Premier Mike Baird resigned the premiership and retired from politics on 19 January 2017, citing family reasons (see NSW Government 2017b). On 28 February 2017 the National Australia Bank (NAB) announced that Baird would commence with them in an executive role in mid-April 2017 (ABC News 2017b).

${ }^{3}$ Barry O'Farrell resigned as Premier on 16 April 2014 following revelations in the course of an inquiry being conducted by the NSW Independent Commission Against Corruption (ICAC) that the [then] Premier had received a gift of a bottle of Penfold's Grange wine valued at A $\$ 3,000$ from Australian Water Holdings (AWH) executive Di Girolamo (see ABC News 2014) Arguably, this episode exemplified a period in NSW political history that was marked by allegations of corruption and poor governance at the level of state politics (see, for example, Grant, Ryan and Lawrie 2015; McKlymont and Besser 2014). Drew (2015, 63) noted that even then the instability at the level of state politics had been responsible for obfuscating planning procedure around Barangaroo, stating: 'It is almost impossible to make sense of what happened. Even professionals find the documents baffling'.
} 
Against the background of casino development in Australia and the Asia Pacific Rim and in Sydney in particular, this article critically examines the process and putative outcomes of Crown's casino at Barangaroo East. The paper is divided into six main parts. In Section 2 we provide an historical account of the development of casinos in Australia. Section 3 examines the immediate spatial context of the Darling Harbour waterfront in Sydney that is also the location of Sydney's first casino, The Star (formerly Star City), before considering the Pyrmont-Ultimo precinct. Section 4 provides an account of the Barangaroo develomment. Section 5 then places the Australian experience of casino development in the global context, considering the hegemony of global over local alongside the power of cosmopolitan image. We challenge the claim of spectacle and iconicity of the development and provide an account of the socioeconomic impacts of casinos in Sydney city centre. Section 6 concludes by calling for reform to the delivery of major projects realse the potential of a resilient global city.

\section{History: Casinos in Australia}

In recent history, major developments in \$ydney have been mired in controversy and conflict: Darling Harbour in the 1980(Daly and Malone 1996; Boydell and Searle 2010) and Star City Casino in the 1990s (Ly)ch and Veal 1998; Searle and Bounds 1999; Searle and Byrne 2002), and now Barangaroo precinct beginning in the late 2000s (Johnston and Clegg 2012; Pham 2015). The XNSW Government's shift in economic strategy, from industrial production and trade to finance, information services and tourism (Daly and Malone 1996, 94-95), has changed the urban landscape in the Pyrmont-Darling Harbour fan at the edge of Sydney's CBD, throwing a blanket over the site's industrial heritage in a staged transformation to a mixed-use precinct offering ample opportunity for business and consumption (see, for example, Hayller, Griffin, and Edwards 2010; Searle 2013, p.138). 
Commensurate with this transformation, historically there have been three clear stages of casino development in Australia: the first in the 1970s with the opening of casinos in Hobart and Darwin; the second in the 1980s with Launceston, Alice Springs, Gold Coast, Perth, Adelaide and Townsville all introducing casinos; and the third commencing in the mid1990s with Canberra, Melbourne, Sydney and Cairns. Australia is now experiencing its fourth stage of development, including new casinos being constructed or planned in Brisbane, Canberra and Sydney. Table 1 depicts these stages, as well as noting the legal basis for the establishment of the casinos, the parent companies and the licensing and exclusivity agreements for each.

Table 1 Casinos in Australia: Stage of development, legislative basis, ownership, licencing and exclusivity

\begin{tabular}{|c|c|c|c|c|c|}
\hline Jurisdiction & $\begin{array}{l}\text { Year of } \\
\text { opening }\end{array}$ & $\begin{array}{l}\text { Legislative } \\
\text { basis }\end{array}$ & Casino & Parent & Licensing and exclusivity \\
\hline \multicolumn{6}{|c|}{ STAGE 1: 1970s } \\
\hline Tasmania & 1973 & $\begin{array}{l}\text { Gaming Control } \\
\text { Act } 1993 \\
\text { (Tasmania) }\end{array}$ & & Federal Group & $\begin{array}{l}\text { The Deed of Agreement between the } \\
\text { Crown and Federal Hotels Pty Ltd } \\
\text { provides exclusive rights for the } \\
\text { Federal Group to operate table } \\
\text { gaming, gaming machines and Keno } \\
\text { throughout the state until } 30 \text { June } \\
2018 \text {. }\end{array}$ \\
\hline $\begin{array}{l}\text { Northern } \\
\text { Territory }\end{array}$ & 1973 & $\begin{array}{l}\text { Gan } \\
\text { Act }\end{array}$ & $\begin{array}{l}\text { Lasseters Alice } \\
\text { Springs }\end{array}$ & $\begin{array}{l}\text { Lasseters } \\
\text { International } \\
\text { Holdings Pty. } \\
\text { Ltd. }\end{array}$ & $\begin{array}{l}\text { Southern NT division exclusivity until } \\
2018 .\end{array}$ \\
\hline Tasmania & 1982 & & $\begin{array}{l}\text { Casino } \\
\text { Launceston }\end{array}$ & Federal Group & $\begin{array}{l}\text { The Deed of Agreement between the } \\
\text { Crown and Federal Hotels Pty Ltd } \\
\text { provides exclusive rights for the } \\
\text { Federal Group to operate table } \\
\text { gaming, gaming machines and Keno } \\
\text { throughout the state until } 30 \text { June } \\
2018 \text {. }\end{array}$ \\
\hline $\begin{array}{l}\text { Northern } \\
\text { Territory }\end{array}$ & & $\begin{array}{l}\text { Gaming Control } \\
\text { Act } 2015 \\
\text { (Northern } \\
\text { Territory) }\end{array}$ & $\begin{array}{l}\text { Skycity } \\
\text { Darwin }\end{array}$ & $\begin{array}{l}\text { Skycity } \\
\text { Entertainment } \\
\text { Ltd. }\end{array}$ & $\begin{array}{l}\text { Northern NT division exclusivity until } \\
2015 .\end{array}$ \\
\hline \multicolumn{6}{|c|}{ STAGE 2: 1980s } \\
\hline South Austra & 1985 & $\begin{array}{l}\text { Casino Act } 1997 \\
\text { (South } \\
\text { Australia) }\end{array}$ & $\begin{array}{l}\text { Skycity } \\
\text { Adelaide }\end{array}$ & $\begin{array}{l}\text { Skycity } \\
\text { Entertainment } \\
\text { Ltd. }\end{array}$ & $\begin{array}{l}\text { The current licence term is until } 2085 \text {. } \\
\text { Exclusivity across SA until } 2015 \text { with } \\
\text { right to receive compensation for any } \\
\text { diminution of value for any change to } \\
\text { the exclusivity. }\end{array}$ \\
\hline Queensland & 1985 & $\begin{array}{l}\text { Casino Control } \\
\text { Act } 1982 \\
\text { (Queensland); } \\
\text { Jupiters Casino } \\
\text { Agreement Act } \\
1983\end{array}$ & $\begin{array}{l}\text { Conrad Jupiters } \\
\text { Gold Coast }\end{array}$ & $\begin{array}{l}\text { Conrad Jupiters } \\
\text { (now Star } \\
\text { Entertainment } \\
\text { Group) }\end{array}$ & $\begin{array}{l}\text { Licence awarded in perpetuity. A } 10 \\
\text { year regional casino gaming } \\
\text { exclusivity agreement expired in } 1996 .\end{array}$ \\
\hline Queensland & 1986 & $\begin{array}{l}\text { Casino Control } \\
\text { Act } 1982 \\
\text { (Queensland); } \\
\text { Breakwater } \\
\text { Island Casino } \\
\text { Agreement Act }\end{array}$ & $\begin{array}{l}\text { Conrad Jupiters } \\
\text { Townsville }\end{array}$ & $\begin{array}{l}\text { Conrad Jupiters } \\
\text { (now Colonial } \\
\text { Leisure Group) }\end{array}$ & $\begin{array}{l}\text { Exclusivity within a } 400 \mathrm{~km} \text { radius } \\
\text { granted in } 1986 \text { for } 15 \text { years, with the } \\
\text { exception of Cairns which was only } \\
\text { excluded for five years. }\end{array}$ \\
\hline
\end{tabular}




\begin{tabular}{|c|c|c|c|c|c|}
\hline & & 1984 & & & \\
\hline $\begin{array}{l}\text { Western } \\
\text { Australia }\end{array}$ & 1987 & $\begin{array}{l}\text { Casino Control } \\
\text { Act } 1984 \text { (WA; } \\
\text { Casino } \\
\text { (Burswood } \\
\text { Island) } \\
\text { Agreement Act } \\
1985 \text { (WA) } \\
\end{array}$ & $\begin{array}{l}\text { Burswood } \\
\text { Entertainment } \\
\text { Complex }\end{array}$ & $\begin{array}{l}\text { Publishing and } \\
\text { Broadcasting } \\
\text { Ltd. }\end{array}$ & $\begin{array}{l}\text { The State must not grant another } \\
\text { licence to a casino and hotel of similar } \\
\text { size and standard as Burswood within } \\
\text { a } 100 \mathrm{~km} \text { radius of Burswood. }\end{array}$ \\
\hline \multicolumn{6}{|c|}{ STAGE 3: 1990s } \\
\hline Victoria & $\begin{array}{l}\text { 1994- } \\
\text { temporary } \\
\text { 1996-permanent }\end{array}$ & $\begin{array}{l}\text { Casino Control } \\
\text { Act } 1991 \text { (Vic); } \\
\text { Casino } \\
\text { (Management } \\
\text { Agreement) Act } \\
\text { 1993(Vic) }\end{array}$ & Crown Casino & $\begin{array}{l}\text { Publishing and } \\
\text { Broadcasting } \\
\text { Ltd. }\end{array}$ & Exclusivity until 2032. \\
\hline $\begin{array}{l}\text { Australian } \\
\text { Capital } \\
\text { Territory }\end{array}$ & 1994 & $\begin{array}{l}\text { Casino Control } \\
\text { Act } 2006(A C T)\end{array}$ & Casino Canberra & $\begin{array}{l}\text { Casinos Austria } \\
\text { International } \\
\text { (now Aquis } \\
\text { Group) }\end{array}$ & $\begin{array}{l}\text { A 99-year lease on licence with } \\
\text { exclusivity until 2012. }\end{array}$ \\
\hline $\begin{array}{l}\text { New South } \\
\text { Wales }\end{array}$ & $\begin{array}{l}\text { 1995- } \\
\text { temporary } \\
\text { 1998-permanent }\end{array}$ & $\begin{array}{l}\text { Casino Control } \\
\text { Act } 1992 \text { (NSW } \\
\text { Government) }\end{array}$ & Star City Casino & $\begin{array}{l}\text { Tabcorp } \\
\text { Holdings Ltd. }\end{array}$ & $\begin{array}{l}\text { The casino licenee was originally } \\
\text { awarded to Sydney Harbour Casino } \\
\text { Pty Ltd for } 99 \text { year from } 1994 \text {, with } \\
12 \text { year exchusivity in NSW. In late }\end{array}$ \\
\hline Queensland & 1995 & $\begin{array}{l}\text { Casino Control } \\
\text { Act } 1982 \\
\text { (Queensland); } \\
\text { Brisbane Casino } \\
\text { Agreement Act } \\
1992\end{array}$ & Conrad Treasury & Conrad Jul & $\begin{array}{l}\text { 195-year licence was awarded in } \\
\text { A ten year exclusivity period } \\
\text { was also awarded for casino gaming } \\
\text { within a } 60 \text { kilometre radius of the } \\
\text { location (now expired). }\end{array}$ \\
\hline \multicolumn{6}{|c|}{ STAGE 4: 2010s } \\
\hline $\begin{array}{l}\text { New South } \\
\text { Wales }\end{array}$ & 2010-expected & $\begin{array}{l}\text { Casino Control } \\
\text { Act } 1992 \text { (NSW } \\
\text { Government) }\end{array}$ & & rownResorts & $\begin{array}{l}\text { A 99-year lease on license beginning } \\
2019 .\end{array}$ \\
\hline Queensland & 2022-expected & $\begin{array}{l}\text { Casino Control } \\
\text { Act } 1982 \\
\text { (Queensland); } \\
\text { Queen's Wharf } \\
\text { Brisbane Act } \\
2016\end{array}$ & Queens Wharf & $\begin{array}{l}\text { Destination } \\
\text { Brisbane } \\
\text { Consortium }\end{array}$ & $\begin{array}{l}\text { 25-year exclusivity from } \\
\text { commencement of operations for } \\
60 \mathrm{~km} \text { from the Brisbane CBD and a } \\
99 \text {-year lease on license. This will be a } \\
\text { direct replacement of the Conrad } \\
\text { Treasury Casino. }\end{array}$ \\
\hline
\end{tabular}

Sources: Crown Resorts 2014; EchoEntertainment Group 2015; Queensland Government 2015; Productivity Commission 2010.

Examining Table 1,the first phase was marked by the regional capital cities of Hobart in Tasmania and Darwin ih the Northern Territory opening modest casinos. Wrest Point Hotel Casino wals valigated and marketed as a destination casino, with the hope of tempting tourists to the Island State to pass through Hobart as a gateway, then to travel to see the island's natural wonders (Hall and Hamon 1996, 31). Yet this did not come to fruition, with the failing business model prompting the owners to request an Electronic Gaming Machine (EGM) license that was subsequently granted by the state (Retail Traders Association 1998).

This had the effect of exacerbating the displacement of local capital from other services, 
alongside engendering the casino's primary client base as residents of Hobart (Retail Traders Association 1998).

There has been little written about the scope of impacts for the Skycity Casino in Darwin, perhaps a comment on its geographic isolation and relative obscurity in Australian economic development, although the data collected for casinos in the Northern Territory suggest extremely skewed impacts of gambling upon the region's residents (Productivity Commission 2010, 394). Despite this dearth of research, in essence the casino touristmodel in Darwin also failed to attract repeat visitors, a situation that also played o t at the Cairds casino in the 1990s (Heazle in Hannigan 2005, 174). Stage 1 also witnessed tha establishment of a small casino in Tasmania and the Northern Territory, the Country Club in Launceston and Lasseters in Alice Springs.

Despite the poor performance of the casino-t urist model, the second phase witnessed a series of medium-sized casinos receiving app al and being established in the larger cities of Perth in Western Australia, Adelaide in Squth Australia and the Gold Coast and Townsville in Queensland in the 1980s. These casinos were developed in line with and modelled after European casinos, informed by a cgnsideration of social impacts alongside those of capital accumulation (Hall and Hamgn 1996, 31).

Arguably, the early 1990s marked a tipping point in the production of consumption (Lynch and Veal 1998, 191; Productivity Commission 2010, 2.1), with the major capitals responding with large, resort-style casinos in Crown's Melbourne Casino, The Star in Sydney and Conrad Treasury in Brisbane. This third wave of casino development mirrored the American model (McMillan, in USRC 2000, 54), with greater emphasis placed upon profits in the climate of increasing regional and global competition. The current developments what we are denoting as the fourth phase - are now looking to the Orient, attempting to mirror successful transformations (Allen Consulting Group 2012). 
While the central concern of this discussion is casinos in Australia, and at Barangaroo in particular, it is important to emphasise that establishments facilitating gambling are no new plaything in Australia, with local registered clubs - essentially non-profit community organisations ostensibly operated to benefit local citizens - incrementally sanctioned to operate Electronic Gaming Machines (EGMs) across six of Australia's seven jurisdictions. NSW was the first state to legalise EGMs in clubs in 1956 (USRC 2000, 49). This prompted an influx of inter-jurisdictional tourism from across the Queensland and Victorianborders (USRC 2000, 49). Seeing their missed opportunity to capture tax revenue, bther states followed suit, allowing EGMs in clubs and hotels as well as in casiros, with Western Australia the only state to reserve the operation of EGMs strichy to casmos (Walker 1998, 21). This led to an expediential growth in the gambling industry aeross Australia in the late 1980s and early 1990s, from approximately A\$7 bi/lion in 1988-89 to A \$17 billion in 199899, then to A\$19 billion in 2008-09 (Product vily Cpmmission 2010, 2.1). Arguably, in jurisdictions other than Western Australia the djfferences between clubs on the one hand and casinos on the other hand have become hard to discern, with the design of the clubs following that of the casinos, favourin spectacle and environments of consumption overlaid with surveillance and contro1 (Klein 2004, 15).

Despite being mimicked by other outlets (clubs, hotels), casinos comprise a relatively small cpmponent of the gambling industry in Australia overall - hence the tax revenues generated from them. ${ }^{4}$ For example, the Productivity Commission $(2010,2.5)$ calculated that, notwithstanding differences across jurisdictions, casinos accounted for only $\mathrm{A} \$ 3.5$ billion or $18 \%$ of all expenditure on major forms of gambling, with EGMs located in clubs and hotels comprising the lion's share (A $\$ 10.5$ billion or 55\%), followed by wagering - horses,

\footnotetext{
${ }^{4}$ For instance, in its Budget Statement 2016-17 the NSW Treasury disaggregates all taxes derived from gambling and betting from FY 2014-15 over the forward estimates to 2019-20. In FY 2015-16 taxes from 'Club gaming machines' and 'Hotel gaming machines' were recorded as A\$778 million and A\$681 million, respectively, with taxes from casinos amounting to A \$246 million (NSW Government 2016, 5-7).
} 
greyhounds, sports-betting (A $\$ 2.8$ billion or $15 \%$ ) and lotteries (A $\$ 2.3$ billion or $12 \%$ ).

Moreover, at that point in time VIP gambling in casinos accounted for only A $\$ 0.6$ billion $3 \%$ overall, less than EGMs in casinos ( $\mathrm{A} \$ 1.4$ billion or $7 \%$ ) and Tables ( $\mathrm{A} \$ 1.4$ billion or 8\%) (Productivity Commission 2010, 2.5).

Of the 13 casinos presently operating in Australia, the only one trading without EGMs is the Canberra Casino, but even this is likely to change as it is earmarked for redevelopment into another large integrated resort (Johnson 2015) that is being designed by Cox Architects (the same firm responsible for The Star in Sydney). Although the Sydney Crown Casing has explicit restrictions mandating that there be no EGMs included in the design, the trajectory of casino development in Australia suggests that there is a high probability of the conversion of some gaming floor space to make way for EGM ganbling (Markham, Doran, and Young 2014). Arguably, from October 2016 this probability increaged due to the Chinese Government curbing the activities of Crown mainland China that were designed to capture the 'high-roller' market, consequently potentially cruelling the business model developed by Crown for Barangaroo and as understood by successive NSW governments (ABC 2017a).

Despite these recent defopments seeing successful enterprises emerge in Asia in the last 15 years has provided case studies for the development of more, and bigger, casino resorts to become competitive in the current global market (Allen Consulting Group 2012). The up vardy mobile Chinese middle-class has been the primary target, and now the tightening of Chinese capital and corruption control in Macau presents opportunities for future Australian resorts to capture that share (Bloomberg 2015); notwithstanding recent events which have seen several Crown employees detained on mainland China - ostensibly for attempting to attract high-rollers to its casinos on Macau and Australia (ABC 2017a). 


\section{Context: Darling Harbour, Pyrmont-Ultimo and Star Casino}

\section{Darling Harbour}

It was in anticipation of the celebration of the bicentenary of Australian settlement in 1988 that the Darling Harbour redevelopment was announced in 1984 (Punter 2005, 68). The project was couched in the rhetoric of attracting external capital and fostering the growing tourist market (Daly and Malone 1996, 96). The state government made plans to transform the ageing waterfront industrial zone that once served as a point of goods distributioninto what is now a mixed-use precinct. This was populated with the usual trimmings: convention centre, public boardwalk, hotels and recreational amenities like the how-closed Sega World indoor amusement park and the much-contested Monorail, a failed infrastructure project that was recently dismantled. To ensure completion for the 1988 bicentenary celebrations, the state took control of planning approvals in what is tow common practice for significant landmark developments in the state capital cifies, acting as both site owner and development authority (Searle and Bounds 1999, 169).

Notwithstanding public baeklash, the withdrawal of support from professional architecture and planning bodhes and evenehanges in leadership of successive governments, the project was completed, although late, and is now generally accepted as successful by most accounts (Daly and Malone 1995, 105). The precinct is currently undergoing a significant facelift, arguably in response to regional competition from other state capitals (Pham 2015, 3). This has necessitated constructing a new convention centre, public realm rehabilitation and a slew of new luxury hotels and residential towers. 
Figure 1: Darling Harbour: Casino locations and sites of major development

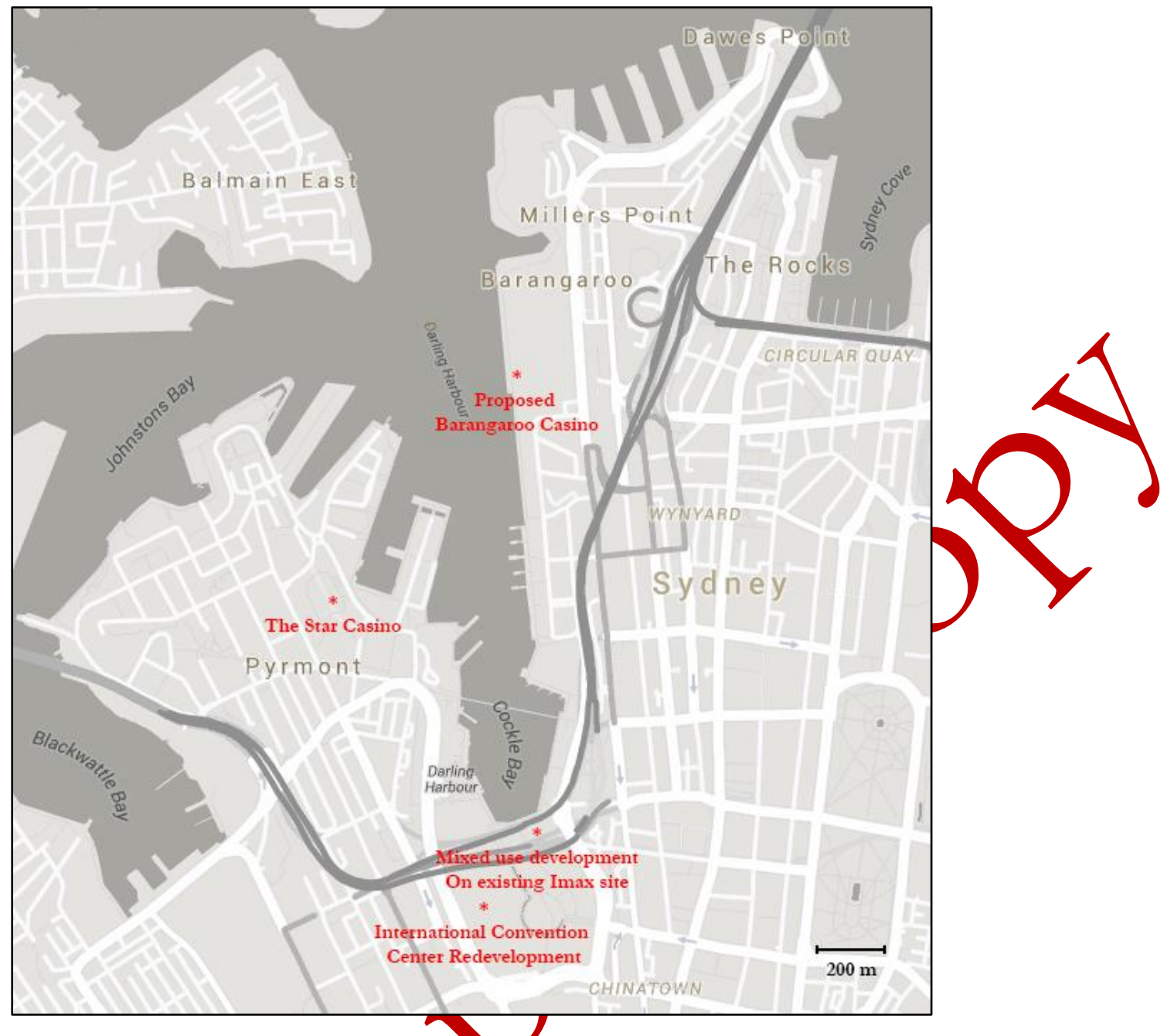

Source: The Authors.

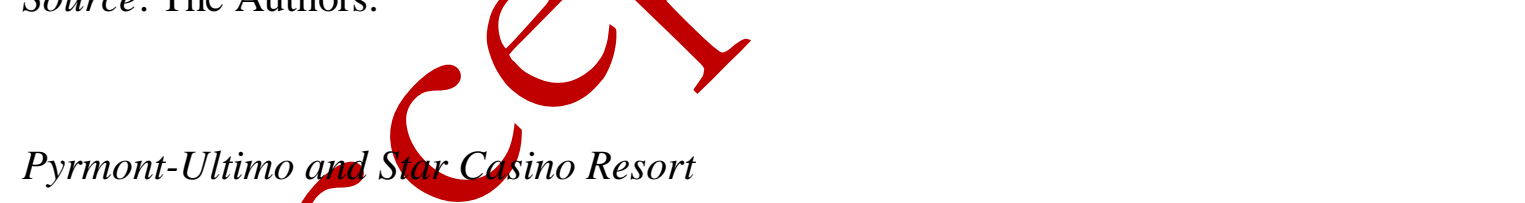

As shown in Figure 1, the Star Casino sits adjacent to Darling Harbour on the western side of the bay. Although objected to by the (then) Sydney City Council (Council of the City of Sydney 1994), the state government announced in 1993 that a casino would be built on the site of the former Pyrmont power station (Searle and Cardew 2000, 368). This development proceeded in spite of a clear lack of citizen participation and council consent, and despite the fact that it contravened state planning policy (Searle and Bounds 1999, 169). State Environmental Planning Policy No.41 (SEPP 41) was gazetted and the development proceeded, enabling the state to receive a one-off license fee payment of nearly A $\$ 400$ 
million (Searle and Cardew 2000, 369) that was marked for reducing state deficit and to fund desperately needed infrastructure projects. Such precedents are now commonplace, with state governments often intervening without consultation or reaching consensus with the local government (Johnston and Clegg 2012, 284; Searle and Byrne 2002, 14).

With the legislative framework for Sydney's first casino set, there was a call for prospective developers to submit design proposals for selection. Yet the development suffered delays and setbacks due to bids being cancelled after investigations found the operators having corrupt connections (USRC 2000, 50). In December 1994 Leighton Properties and Showboat were announced as the winners, with a tepporary casino built on an adjacent site in 1995, functioning both as a test-bed for the main casino and to generate significant revenue before the permanent casino oponed for business in November 1997. Cox Architects were appointed to design the casino, along with the convention centre (also on Darling Harbour). Following Philip Cox's adnssion that The Star was 'my worst building by far' and that he wouldn't be involved in a casin project again (Hasham 2013), his firm has since designed proposals for the cerino resort in Canberra.

The Star Casino, with to prime setting on the Sydney waterfront, offers easy access to punters with its own dedicated light rail, bus and ferry stops. Less conspicuous than the resort casinos of Las Vegas, the Star Casino integrated resort, although dominating in stature, fits more infoits surrounds, occupying an expansive block built to a relatively low height with the podiun reaching three storeys, the recently completed Darling Hotel at 12 storeys, and the Astral Tower and Residences at 15 storeys. The integrated resort attracts and contains patrons with an array of food and beverage offerings, and entertainment and conference facilities. The design of the casino resort is spatially read as a cohesive urban interior without clear distinction or delineation of separate functions throughout. Recent facelifts have modernised the exterior, adapting the façade to become a performative element as a backdrop 
to a changing light show. This shiny, undulating surface continues to the interior, blending the gaming, retail and dining experiences. The gaming gross floor area (GFA) totals 4.3 hectares (the Melbourne Crown is 5 hectares), although the interior gaming floors have been planned for expansion.

Since opening in 1997, the Star Casino has undergone regular upgrades. As the Star Casino's exclusivity agreements with the NSW Government will lapse in 2019, a new era of competition is emerging with a partnership to deliver a 6-star Ritz-Carlton branđed hotel to compete with Crown's offering at Barangaroo.

Table 2 Star Casino Resort and Crown Casino Resort compared

\begin{tabular}{|c|c|c|}
\hline & The Star Casino Resort & Resort \\
\hline 1. Existing site & Power station & Industrial dock \\
\hline 2. Date announced & 1989 & 2009 \\
\hline 3. Date approved & 1994 & 2016 \\
\hline 4. Date opened & chino 1997 & 2020 (estimated) \\
\hline 5. Licence cost & $\begin{array}{l}\text { Initial exclusive licepee (199-2009) and 99-year } \\
\text { operating licence, } \$ 376 \text { milion, extension of exclusive } \\
\text { licence (2009-2019), A\$250 million }\end{array}$ & $\begin{array}{l}\text { 99-year operating license } \\
\text { A } \$ 100 \text { million }\end{array}$ \\
\hline 6. Gaming GFA & & Up to 2 hectares or $20 \%$ GFA \\
\hline 7.EGMs & & No \\
\hline 8. Theatre & & No \\
\hline $\begin{array}{l}\text { 9. Residential or } \\
\text { site }\end{array}$ & Yes & Yes \\
\hline $\begin{array}{c}10 . \\
\text { site }\end{array}$ & 5 -star & 6-star \\
\hline $\begin{array}{l}\text { 11. } \\
\text { height }\end{array}$ & $\begin{array}{l}\text { Current } 75 \mathrm{~m} \\
\text { Proposed } 215 \mathrm{~m}\end{array}$ & Approved $275 \mathrm{~m}$ \\
\hline
\end{tabular}

Sources: Chew 2015; Daly and Malone 1995; Department of Planning 2016; Drew 2015; Hall and Hamon 1996; Lynch and Veal 1998; Markham, Doran, and Young 2014; Searle and Bounds 1999; Searle and Cardew 2000; The Star 2016, n.d.; Walker 1998. 


\section{Barangaroo}

The Barangaroo precinct (see Figure 1) is located on the edge of the CBD on a former shipyard, with adjacent working-class cottages that have mostly been rebuilt, renovated or converted to high-quality commercial or residential property. The site is also close to Millers Point, where rows of public housing are marked for sale and conversion that will change the social mix of the neighbourhood. ${ }^{5}$ The precinct was initiated through an international competitive process that attracted designs from a wide field of entries from both locanand foreign firms. Although it was not the winner of the competition, the seleeted des gn cane from a consortium led by Lendlease. The Barangaroo precinct deve opment is a $4 \$ 6$ billion project on 22ha of land on the last open site in the City of Sydney. It,has predictably piqued the interest of a wide range of stakeholders and commentators who have made their opinions known through responses to calls for public submissions and reporting in mainstream news channels (Pham 2015).

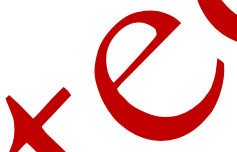

As was there conflict in the competition process, there has also been no shortage of contention through the life of the delopment, with the Barangaroo process mirroring that of the Darling Harbour precind 1988 (see Fable 2). The Barangaroo precinct is essentially an annexed parcel of land under tate control in what is otherwise territory under the City of Sydney's jurisdiction. The City of Sydney Council, and in particular the Lord Mayor, Clover Moore, has been critical of the Barangaroo development, with the latter resigning from her role on the Barangaroo Delivery Authority (BDA) in September 2010, citing a lack of transparency through procedure and information dissemination, and poor community consultation (Moore 2010). It can be argued that Sydney is the most important city in Australia, and it is images of Sydney that are most often conjured and recalled when considering Australia as an entity. It is also the city contributing most to GDP (SGS

\footnotetext{
${ }^{5}$ The NSW Government (2017a) has launched a website advertising the properties for sale and highlighting attractions in the surrounds.
} 
Economics and Planning 2014, 3; 2017). As such, the configuration of its public space is important not only for its residents, but perhaps also its temporary residents, namely tourists visiting and transiting the city. ${ }^{6}$

The Barangaroo precinct is divided into three parts: South, Central and Reserve.

Barangaroo South was originally envisaged as the commercial sector that concentrated built form to the southern end of the site. The approved urban design characteristics have instead expanded the massing and shifted the apex of the site towards the centre of the preainct. This southern sector also seeks to expand its global credentials with significant evelopment blocks and the tallest buildings in the precinct designed by world-renowned architecture studios: three slim residential towers designed by Renzo Pian Building Workshop and the Crown Casino Resort designed by Wikinson Eyre.Barangaroo Central is a mixed-use sector that is yet to have its design finalised, and Barangar oo Resepve, completed in 2015, save for a designated cultural space below the reserve clled the 'Cutaway', features a 'naturalised' headland park designed by Peter Walker and Partners and Johnson Pilton Walker. As of June 2016, Barangaroo South has seen the contruction of the commercial towers completed - one of the initial precepts of the Brangarondeyelopment was to address the shortage of primegrade office space in Sydney to attract global firms that require large contiguous floor-plates (Sussex and Pen 2011)

Yet the entire development has been littered with controversy. As noted in the Introduction, early indications of the casino were presented as an unsolicited proposal in 2009, with details held in secrecy as commercial-in-confidence and in direct consultation

\footnotetext{
${ }^{6}$ Former Prime Minister Paul Keating imposed his influence on the design of the precinct, especially in the early stages of design development. Keating was first involved as a juror for the East Darling Harbour International Design Competition (now Barangaroo) and chaired the Design Excellence Review Panel (DERP), raising concerns of conflicts of interest (Stickells 2010). He successfully argued for the design and construction of the headland but distanced himself after the introduction of the casino resort into the masterplan (Davies 2015). Architectural historian Philip Drew $(2015,62)$ describes Keating as: 'An opinionated amateur', commenting of the Keating-led design: 'Sydney already has eighteen natural headlands and does not need another costing \$177 million'.
} 
with the NSW Government (Chew 2015). Former Head of the NSW Independent Liquor and Gaming Authority, Chris Sidoti, stated:

There was no public tender process and there was no public inquiry at any stage ... as to the public benefit involved in this ... I think that casinos are big money spinners and a licence to print money ...

The parliamentary scrutiny ... was to my mind fairly superficial ... I don't think there was an appetite for thorough scrutiny ... I think there was a wish simply to get the job done ... (Sidoti, in ABC 2017a).

Given a planning context where consultation with the community is legis atively mandated at the local government level, not just in NSW but also in many jurisd ctions nationally (see Grant and Drew 2017, 226-243) this lack of a public inquiry or tender process is highly atypical $^{7}$. Further, given that The Star is located in such close proximity it is difficult to justify the Crown Casino Resort at Barangaroo as a unique propasyd. In 2010, MOD4 was approved by the Minister for Planning for a hotel on a fly built pier (Department of Planning 2010), and in 2013 Crown paid a A $\$ 100$ million fee (notably less than that paid for Star City; see Table 2, Row 5) for the casino license to the NSW Government (Chew 2015, 30), allowing it to begin operating after Star Casing's axclusivity agreement lapses.

In particular, the unpregedented siting of a hotel on a newly built pier approved in MOD4 faced fiefce opposition. The impact of the proposal would significantly change the built form principles of concentrating the tall buildings to the south of the site, instead shifting the apex north and west, extending off the foreshore and gaining privileged views over the Sydney CBD. Facing public backlash, this proposal was superseded by MOD8, which was approved in June 2016, with the hotel trading its position back onto the existing foreshore but adding additional bulk in the podium - over 100 metres taller - and is now defined by its principal function as a casino resort that incorporates a 6-star hotel and high-

\footnotetext{
${ }^{7}$ This lack of a formal consultation process did not stop an 11,000-signature petition opposing the development being submitted to parliament by the Sydney Lord Mayor Clover Moore in May 2011, forcing the issue to be debated in the Legislative Assembly (SMH 2011; see also Drew 2015, 64).
} 
end residential accommodation. From the available documents, the Crown Casino Resort will be clad in reflective glass, standing as an iconic landmark building and justified as becoming Sydney's global calling-card. The building imposes itself on the foreshore promenade, dominating views from the public domain. Modelled after the petals of a flower, the Crown Casino Resort will be adorned with no fewer than 12 Crown logos on every face of its façade, from ground level to its uppermost point. Liberally using Crown's brand visually scattered across the building calls to question the self-imbued 'iconic' status that was used tojustify the design.

The planned restriction to limit the casino to VIP gamblers propagates and extends notions of exclusivity. From the exterior thresholds, high-end dining expands the licensed area onto an already narrowed boardwalk, further restricting public use of an apparently public space. The planned gaming space is much snaller thon the Star Casino, with approval for a maximum 2 hectares or $20 \%$ GFA. The yo flgors of VIP gaming in the podium are supplemented with an VIP area on the $25^{\text {th }}$ and $26^{\text {th }}$ floors.

\section{Contemporary globar context}

Since casinos were developed in Lds Vegas, they have undeniably been the world standard for creating profitable landscapes of consumption and desire. Yet by the turn of the $21^{\text {st }}$ century attention had shifted to the Orient, with many states legalising gambling and a couple of city-tates exceeding the turnover and profit of Las Vegas, which was first eclipsed by Macau in 2007 (PriceWaterhouseCoopers 2011). The economics of casino gambling depend heavily on the mobility of people and capital. With the frames of reference constantly changing, modelling requires diligent updating of information relative to cited examples. Reports and assessments are often dated before they are published. Even more problematic is citing recent publications that quickly become dated under entropic global markets. For example, PriceWaterhouseCoopers in 2011 issued the Global Gaming Outlook, including 
projections for Macau's revenue forecast for 2011-2015 at US\$34,608 million, US\$44,862

million, US\$52,553, US\$57,680 and US\$62,167 (PriceWaterhouseCoopers 2011). However, recorded returns were US\$33,608, US\$38,017, US\$45,093, US\$43,940 and US\$28,920, respectively (UNLV 2015; GMA News Online 2016). Considering the discrepancy between these forecast and recorded figures, discord between expectations and results are also likely in future developments.

Together with Macau, the development of casinos in the city-state of Singapone represents a new turn to an Oriental phase of casino development. The success of these ventures has also shifted the global locus of casino-centric developpent around these active hubs. As an island city-state, Singapore had its own challenge and to capture these global flows of capital had to respond to its own environmental limitations (Henderson 2012, 72). Considering the severe shortage of land in Singapo e, the government exhibited significant foresight in devising a long-term concept pla 1971 1, overseen by the Urban Redevelopment Authority (URA) that planned for a direction of development over a 40- to 50-year timeframe, including reytsions eyery decade (Henderson 2012, 72). More detailed master-plans followed from bese medium-long-term plans, with the goals of maintaining a balance of growth, character and heritage. The Macau context follows similar but different constraints: agai with highly restricting geographical boarders, the state has historically relied on landreclamation, with $50 \%$ of the territory reclaimed from the sea (Simpson 2014, 831).

In Macau the most recent significant impact on growth and generation of revenue has been the promotion of Xi Jinping to the position of General Secretary of the Communist Party of China (Chow 2015, 4). Since his appointment there has been a serious drive to reform corrupt practices and money laundering between China and Macau, and this is having 
significant impacts upon the profits of Macau's casino resorts (Schneider 2015, 122), including that of Crown's Studio City venture with Melco International (see ABC 2017a).

The documents submitted by Crown Resorts supporting their development of a high rollers casino at Barangaroo (Allen Consulting Group 2012) reveals significant attention being paid to attracting the rising Chinese middle-class and to capitalise on their tastes and interests as easing travel restrictions contribute to their mobility and ability to access the Australian market. For instance, 'White Papers' from the NSW Government anc casind development documents make comparisons with Macau and Singapore (Alen Consulting Group 2012; Productivity Commission 2010). This has been echoed more tecently by the Star on its website: commenting on the unveiling of its hotel proposal, China is the only country singled out, highlighting the opportunities that Chmese tourists bring to the consumptive agglomerations that centres on casino tourism (The Star, ndy; see also The Star 2016, 2). Although geographically it may seem stitable to draw upon the casinos of Macau and Singapore by way of example, in reality the deyelopment in Sydney is functionally closer to that of the Las Vegas market, closer to a abula rasa typology with a dominant unitary market of casino tourism rather than anembedded development in an urban centre. Arguably, the archipelagos of spectacle from Las Vegas to Macau and Singapore are inherently not the best or most suitable models of comparison to drive the urban development of Sydney to compete for external capital in the face of slowing domestic production and exports (see IMF 2017). This global 'best-practice' comparison leads to a temporal-spatial dissonance that disproportionately affects the residents and non-users. This spatial zone around the proposed Barangaroo casino resort radiates from its privileged centre through the entire precinct from the spectacle of the landmark building, the 'elite' intended audience and the encroachment on the public realm. 


\section{Image of the city}

Dissemination of city image often involves agglomerations of iconicity collated and packaged to deliver attractive visages that compel the tourist gaze to focus on the city. Icons of urban forms are often the highlights of the skyline that are, in most cases, tall buildings and monuments. The mainstays of iconic architectural elements in Sydney include the Harbour Bridge, Opera House and Sydney Tower. At 275m tall, after Sydney Tower the Crown Resort will be Sydney's tallest, but sited on the foreshore's edge it will havergater impact on the surrounding open public space. In his study of Melbourne's skyline, Dovey (2010) noted the impact of these corporate towers as leading to the radualexpropriation of the city (Dovey, in Sklair 2010, 148). As the Crown Resort in Sydney will be positioned at the water's edge, the impact will be greater than thatowers in Dovey's (2010) study. This domination of corporate imagery and the ideologica shift from a public to private city can be visualised in what Norman Klein terms 'scripted spaces' (Klein 2004, 10). Just as Haussmann's Paris project expelled hundreds of thousands of people in the 1870s (Urry and Larsen 2011, 160) Sydney will als be sanitised, clearing the paths of the tourist gaze to see exactly what the state dictates

Sydney is positioning itself in the direction of a unique global city that is looking closer to the Indo-Pacif c, as alluded to in recent White Papers (Australian Government, 2013). Except Singapore, which has redefined itself through its casino resorts (Seng 2005, 259-260), Sydney is the only Alpha + or Alpha ++ city on the Global and World City database with a major casino resort (see, for example, GaWC 2012). With the two casinos soon to be within eyesight and 1000 metres of each other, there is a strong weight of shifting identity to a city that chooses to redefine itself from an exemplar of high liveability and lifestyle to that of monocultural consumptionscapes within which the casinos will be dominant. 
As Pop Art eroded the distinction between historically understood high and low art, so too has the international style opened the market for buildings of distinctive yet questionable taste in the public eye. The erosion of hegemony between buildings and monuments and architecture and monument (Sklair and Gherardi 2012, 58) has allowed the dominant public opinion, as directed through media and press popularity, to imbue any building as icon. As much as Crown Resorts predicates the need for an iconic building, justifying the size height, function and position on the waterfront to allow their allegory to continue, it places in their hands far too much power to dominate the public realm in what should be genuingly public space. Justifying the position and size of the Crown Resorts buildin as a necessary spectacle overturning the state planning policy (Drew 2015, 64) is hubristic to say the least.

Otherwise stated, it ought to be recognised that these developments are spawned from success stories incumbent on local specificity (e.g., the Bitbao Effect), ${ }^{8}$ and these 'bestpractice' models of development are problem atic: mpbilities of ideology importing constructs built in specific contexts then transplanted in foreign landscapes. The desire to construct integrated resorts that follow closely the models of the Orient, sites that lack the historical specificity of cities such as Yyey, leads to the development of dull, inert cities (Jacobs 1961, 442). This proces s of reterritorialising the urban landscape also draws comparison to the colonial past, on this very site and dictating 'a new form of "colonisation", crowding out the potentia for local invention' (Healey, in Hillier 2013, 105). The urban landscapes of cities develop slowly over time, gradually forming their own genius loci. These processes are inherently messy and as such do not have the luxury of a tabula rasa approach to development.

\footnotetext{
${ }^{8}$ The 'Bilbao Effect' refers to the revitalisation project of the existing industrial waterfront in Bilbao, Spain through the conflation of the star architect designing iconic buildings, museums and cultural artefacts attracting the growth of tourism into the city. This exemplar has drawn the gaze of numerous ailing cities, spawning numerous attempts to mirror this successful transformation (see Plaza 2000).
} 
Selling the image, marketing and image agglomerations

As we imitate global exemplars ascribing the waterfront to a successful platform to share to the world, and after using key images of famous structures and views to frame the perspective, how are we to shift the gaze from global Sydney to local Sydney? The Opera House and Harbour Bridge are recognisable icons, with the seduction of Bondi's beach and the Blue Mountains stretching the spatial imaginary. As the contingent forms of redevelopment in post-industrial cities, waterfront developments are the jewel in the crown for cities exemplifying their capacity for innovation, reputation and seduction. Bu withodit any indicators or visual markers to direct our gaze, how are we to make the clain that these environments are specific to their context? The casino resorts of Macau and Singapore certainly exhibit the spectacle and fanfare to capterro our attention, but let us consider the existing character of Sydney before the complete reformation of its image.

Bourdieu's (1984) habitus is something ignorgd in the face of globalisation and international competition that is having significant impact on the spaces being constructed in our cities. The identity that is built up over the course of many decades holds for little in the face of developers promising bilions in tax revenue and revitalised landscapes, as the case of The Star and incoming Crown Casino Resort at Barangaroo. Closing the eastern edge of Darling Harbour, Barangaroo follows this as the defining characteristic for its development, consunfptionscapes that implicitly deny access by way of design determinism and spatial constructipn. These development strategies limit human habitation to predefined consumptive activities and the temporal-spatial effects of these strictures prioritise the supply of leisure for a global audience. 
Although gambling addiction affects a small number of people (Productivity Commission 2010) the social cost is disproportionately weighted to those in weaker economic positions. It is difficult to agree on an accurate figure of the cost, with some estimates of the worst case over 10 times that of the best cases, but in Australia the Productivity Commission has drawn a figure of $\mathrm{A} \$ 4.7$ billion a year (Productivity Commission 2010,2) which still leaves their estimate of total economic gain, including the recreational value, as between $\mathrm{A} \$ 3.7$ and A $\$ 11.1$ billion. As a conflation of quantitative and qualitative measures, this interpretation and resolution can be problematic. As gambling is a legalised industry, and legislation fals under state government, duty of care essentially falls to the state (Walker 1998, 25) and, considering who is harmed, it is reasonable to assume that the may be other actors affecting the laws and regulations.

In the case of The Star in Pyrmont, establishing a casino resort in an existing residential neighbourhood accelerated the gentrifying process, pushing up market prices of buildings and units, and also displacing other business activities, instead pushing revenue through the casino (USRC 2000, 57). With the anticipated Crown Casino Resort, if it proceeds according to plan, the casino and its surround will be limited to 'high-rollers', shorting any chance of social cohesion and di ersity in the area. On the other hand, if the outcome follows the casino resorts that have been developed in Australia thus far, the socioeconomic consequences will shift from exclusion reverting to one of social harm associated with EGM gambling. The net gain is limited to the taxation returns to the NSW Government and the benefits of these consumptionscapes to casual users and residents are limited to the use of the casino resort services that will be strictly pay-per-use. Moreover, it is worth emphasising that the NSW Government is budgeting for a marked increase in taxation revenue from casinos over the forward estimates, from A $\$ 282$ million in 2017-18 to A \$414 million in FY 2019-20 - a forecast increase of $13.9 \%$ in one fiscal year; otherwise stated, the NSW Government is 
expecting a significant increase in revenues from casinos when Crown is scheduled to become operational in 2019-20 (see NSW Government 2016, 5-7).

\section{Conclusion and observations}

Although Sydney is widely considered the financial and creative capital of Australia (Hu, Blakeley, and Zhou 2013, 442) the increasing reliance on, and power given to, the defvelopers of casino resorts has led to an increasingly monocultural spatial outcome of Sydney foreshore. These developments that are dominated by a single actor create environments that lack vitality, with a commercial agenda predicated primarily on fut re - and perhaps unrealistic - expectations of a continuing influx of Chinese casino toprism dollars (see ABC 2017a). This has followed from the success of casinotourist models of the Orient with the operators of Crown forming a partnership with its Asian colnterpart.

As discussed in this article, the Barangaroo preinct development, and the Crown Casino resort in particular, continue a cycle of najor project development where the state has taken control from local government ove project determinations (see Table 1). This nested hierarchy has also allowed controversial projects like the Crown Casino to pass through planning processes without opportunity for thorough interrogation and public debate and, arguably, where the promise of increased state revenues has quickened the process in a way that is upjustiftable. Waterfront developments are significant projects and should be overseen by higher iees of government, but that should not discount the importance of the local over global loci. Although Sydney is a 'Global City', it is also home to an existing resident base. In this article there has not been space to examine the lack of public housing in the surrounding area (Pham in press), nor the impact of the casino resort on its future provision. Yet the Crown Casino resort should be viewed with the implicit effects of its erection, not just the economic opportunities of taxation receipts generated. This spatial agglomeration 
melds into the agglomeration of its imagery in justifying the resort as requisite promoting Sydney's global attributes.

We have found that, instead of planning for diversity, the outcomes have intensified land use in successive foreshore developments. Pushing the limits of design is essential to the invention or reinvention of an urban renewal project such as Barangaroo, but transformation and progression could be achieved more implicitly through structural reform. This strategy rekindles the position of many urbanists of the past, from Mumford and Jacobs (1961) to Jencks (2006) and Gehl (2013). All observed the importance of identity and community successful built environments that are contingent on a multitude of mall statements. These are the details that bind identity to environment, generating the baseline for vibrant, inclusive communities that are becoming increasingly more dufficult to achieve in a rapidly globalising city. This introspection may be at first appear to slow or hinder the rate of development, but in the long term, planning for the future appear to be the counter-argument for sustainable development.

\section{References}
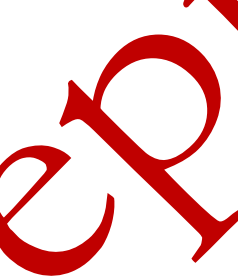

ABC [Australian Broadcasting Corporation]. 2014. NSW Premier Barry O'Farrell to resign over 'massive metnory fail' at ICAC. 17 April. Available from:

htp:ywwazb.net.au/news/2014-04-16/nsw-premier-barry-ofarrell-to-resign-overicactorange-wine/5393478 [Accessed 11 March 2017].

ABC [Australian Broadcasting Corporation]. 2017a. Crown Confidential: Packer's losing hand. Four Corners [investigative current affairs program]. Monday 6 March. Available from: http://iview.abc.net.au/programs/fourcorners/NC1704H005S00\#playing [Accessed 11 March 2017]. 
ABC [Australian Broadcasting Corporation]. 2017b. Mike Baird moves to NAB: Former NSW Premier takes senior bank role. ABC News 28 February. Available from: http://www.abc.net.au/news/2017-02-28/mike-baird-former-nsw-premier-takes-senior-

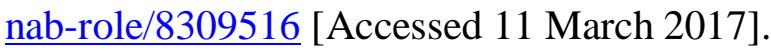

Allen Consulting Group. 2012. Crown Sydney proposal: An economic benefit assessment'. Accessed 26 April 2016 http://www.crownresorts.com.au/CrownResorts/files/1d/1db9d9a2-3de5-4072-9a-4a486bb427cf8c.pdf

BDA [Barangaroo Delivery Authority]. 2013. Barangaroo Delivery Authoyity. Ayoúlable from: http://www.barangaroo.com/discover-barangaroo barangaroo-deliveryauthority.aspx [Accessedonsulted 11 March 2017].

Bloomberg. 2015. Macau crackdown brings windfall for asinos from South Korea to Cambodia. Available from: http://w w Loon/berg.com/news/articles/2015-03-05/asiacasinos-woo-chinese-gamblers-with-nos-jobs-and-peking-duck [Accessed 14 February 2016].

Boydell, S., \& Searle, G.H. 2010. The contemporary urban commons: a case study of Darling Harbour, Sydney. In COBRA Legal Research Symposium. RICS Org.

Chew A. 2015. Use of lunsolicited proposals for new projects-the approaches in Australia. Edypeanyrocurement \& public private partnership law review 10: 29-34.

Chow, D. Y.2015. How China's crackdown on corruption has led to less transparency in its enforcement of its anti-bribery laws. UC Davis law review. Accessed 26 April 2016 http://lawreview.law.ucdavis.edu/issues/49/2/Symposium/49-2_Chow.pdf

Crown Resorts. 2014. Restricted gaming licence issues for Crown Sydney. [Media release]. Available from: http://www.crownresorts.com.au/CrownResorts/files/f9/f9d4d1c77301-478a-af73-ad5d26009c4b.pdf [Accessed 18 March 2017]. 
Daly, M., and Malone, P. 1996. Sydney: the economic and political roots of Darling Harbour. In P. Malone (Ed.). City, Capital and Water: 90-108.

Davies, A. 2015. Force of nature: How Keating restored the headland at Barangaroo. Sydney Morning Herald, 21 August. Available from: http://www.smh.com.au/nsw/paulkeatings-vision-for-the-headland-park-at-barangaroo-20150821-gj4hg9.html [Accessed February 14, 2016].

Department of Planning. 2010. Modification of Minister's approval major project number MP06_0162 (MOD 4). Sydney.

Department of Planning. 2016. Modification of Minister's approval major project number MP06_0162 (MOD 8). Sydney.

Drew, P. 2015. The betrayal of Barangaroo. Quadront, 59(10): 8

Echo Entertainment Group (2015), Destination Brisbane consortium and Queensland Government enter in agreements for Q een's Wharf Brisbane. [ASX announcement]. GMA News Online 2016. Macau gaming revenue fell 34\% in 2015. Available from: http://www.macaunews.con/mo/content/view/3799/13/lang,english/ [Accessed 14 February 2016].

Grant, B. and Drew, J 2017. Local Government in Australia: History, Theory and Public Policy. Singapore; Springer.

Grant, B., BJan, R. and Lawrie, A. 2015. Dirty hands and commissions of inquiry: An examination of the Independent Local Government Review Panel (ILGRP) in NSW, $y$

Australia, in Beard, M. and Lynch, S. (eds), Conscience, Leadership and the Problem of 'Dirty Hands' (Research in Ethical Issues in Organizations), Emerald/Insight, UK, pp. 19-39.

Hall, C. M., and Hamon, C. 1996. Casinos and urban redevelopment in Australia' Journal of Travel Research, 34(3): 30-36. 
Hannigan, J. 2005) Fantasy City: Pleasure and Profit in the Postmodern Metropolis. London: Routledge.

Hasham, N. 2013. 'My worst building by far': Philip Cox hits out at The Star design. Sydney Morning Herald. Available from: http://www.smh.com.au/nsw/my-worst-building-byfar-philip-cox-hits-out-at-the-star-design-20130913-2tooz.html [Accessed 14 February 2016].

Hayllar, B., Griffin, T., and Edwards, D. 2010. City Spaces-Tourist Places. London Routledge.

Henderson, J. C. 2012. Planning for success: Singapore, the model ity-state? Juurnal of International Affairs, 69-83.

Hillier, J. 2013. Troubling the place of the border on territory, community, space and place. Australian Planner, 50(2): 103-108.

Hu, R., Blakely, E. J., and Zhou, Y. 2013. Bengmaking the competitiveness of Australian global cities: Sydney and Melbourne in the global context. Urban Policy and Research, 31(4): 435-452.

IMF [International Monetar Rund]. 2017. Australia. IMF Country Report No. 17/42. Available from: tttps://Www.imf.org/en/Publications/CR/Issues/2017/02/09/Australia2016-Artic e-IV-Consultation-Press-Release-Staff-Report-Staff-Statement-and-44632 [Accessed 12 March 2017].

Jacobs, J. 961. The death and life of great American cities. Vintage, New York.

Johnson, S. 2015. Cox Architecture to design Canberra casino. In ArchitectureAU Available from: http://architectureau.com/articles/cox-architects-design-new-casino-after-disaster/ [Accessed 14 February 2016].

Johnston, J., and Clegg, S. 2012. Legitimate sovereignty and contested authority in public management organization and disorganization: Barangaroo and the grand strategic 
vision for Sydney as a globalizing city. Journal of Change Management 12(3): 279299.

Klein, N. M. 2004. The Vatican to Vegas: A History of Special Effects. London: New Press. Lendlease (n.d.a.). About us. Available from: http://www.lendlease.com/au/company/aboutus/ [Accessed 11 March 2017].

Lendlease (n.d.b.). Barangaroo South. Available from: http://www.lendlease.com/au/company/about-us/ [Accessed 11 March 2017]

Livingstone, C. 2005. Desire and the consumption of danger: Electronic gaming machines and the commodification of interiority. Addiction Research and Thedry, 13)6):523-534.

Lynch, R., Veal, A. J. 1998. The Casino in the post-industrial city: The social and economic impact of the Sydney casino. Leisure Management: Issues and Applications: 181-196.

Markham, F., Doran, B., and Young, M. 2014. Our most profitable gambling venues are the most harmful. The Conversation. Ayailable from: https://theconversation.com/ourmost-profitable-gambling-venues-are-the-most-harmful-25977 [Accessed 26 April 2016].

McClymont, C. and Besser, 2014. He Who Must Be Obeid. Melbourne: Vintage Press.

McKenny, L., Saulwick, J. 2015. Central Barangaroo buildings increase again thanks to new station. Sydney Morning Herald 27 November. Available from:

http./Wwy smh.com.au/nsw/central-barangaroo-buildings-increase-again-thanks-tonew- Yation-20151126-gl8wr7.html [Accessed March 2016].

Moore, M. 2010. Moore quits Barangaroo team. The Sydney Morning Herald 22 September. Available from: from http://www.smh.com.au/nsw/moore-quits-over-barangaroorailroading-20100921- 15ldg.html [Accessed 13 August 2016].

NSW Government. 2009. Barangaroo Delivery Authority Act 2009 No. 2. Available from: http://www.legislation.nsw.gov.au/\#/view/act/2009/2?autoquery $=($ Content\%3D $((\% 22 \mathrm{~b}$ 
arangaroo\%22)) $\%$ 20AND\%20((Type\%3D\%22act\%22\%20AND\%20Repealed\%3D\%2 2N\%22)\%20OR\%20(Type\%3D\%22subordleg\%22\%20AND\%20Repealed\%3D\%22N \%22))\&dq=Document\%20Types\%3D\%22Acts [Accessed 11 March 2017].

NSW Government. 2016. Budget Statement 2016-17. Budget Paper No. 1. Available from http://www.budget.nsw.gov.au/ [Accessed 12 March 2017].

NSW Government. 2017a. Millers Point. Available from: https://rediscovermillerspoint.com.au/ [Accessed 12 March 2017].

NSW Government. 2017b. Statement from Mike Baird. Available https://www.nsw.gov.au/your-government/the-premier/media -leases-from-thepremier/statement-from-mike-baird/ [Accessed 11 March 201h].

Pham, K. 2015. Vanity unfair - examining the impact of deyelopment authorities on the designation and development of public ppace: Barangaroo case study. In State of Australian Cities Conference.

Pham, K. (in press). Clearing stocl of the invisible: Effects of cosmopolitan power on the supply of affordable housing. In Artopoulos, G. and Kirsten, D. (Eds.), From conflict to inclusion in housing - Perspectives on the interaction of communities, residents and activists with the potitics of the home. London: University College London Press.

Plaza, B. 2000. Evaluating the influence of a large cultural artefact in the attraction of tourism the Guggenheim Museum Bilbao case. Urban Affairs Review, 36(2): 264-274

PriceWaterhouseCoopers. 2011. Global gaming outlook: The casino and online gaming market to 2015. Available from: https://www.pwc.com/gr/en/publications/assets/global-gaming-outlook-2011-2015.pdf [Accessed 26 April 2016]. 
Productivity Commission 2010. Productivity Commission Inquiry Report: Gambling Available from: http://www.pc.gov.au/inquiries/completed/gambling-2009/report [Accessed 26 April 2016].

Punter, J. 2005. Urban design in central Sydney 1945-2002: Laissez-faire and discretionary traditions in the accidental city. Progress in Planning, 63(1): 11-160.

Queensland Government. 2016. Australian Gambling Statistics: 32 ${ }^{\text {nd }}$ Edition. Available from: http://www.qgso.qld.gov.au/products/reports/aus-gambling-stats/index.php Aecessed 13 March 2017].

Retail Traders Association of Tasmania. 1998. The effect of gambling, particularyygaming on the retail industry and small business in Tasmania. A vailable from: http://www.pc.gov.au/inquiries/completed/gampling/submissions/sub123/sub123.pdf [Accessed 14 February 14, 2016].

Schneider, S. 2015. China deals Macau a bad hand,Jaming Law Review and Economics, 19(2): 122-123.

Searle, G., 2013. Case study window-disfourse, doctrine and habitus: redevelopment contestation on Sydneys harbor-edge. In Young, G., and Stevenson, D. The Ashgate research companion to planning and culture, pp. 135-152. Routledge, London.

Searle, G., and Bounds.M. 1999. State powers, state land and competition for global enterkainment: The case of Sydney. International Journal of Urban and Regional Research, 23(1): 165-172.

Searle, G., and Byrne, J. 2002. Selective memories, sanitised futures: Constructing visions of future place in Sydney. Urban Policy and Research, 20(1): 7-25.

Searle, G., and Cardew, R. 2000. Planning, economic development and the spatial outcomes of market liberalisation. Urban Policy and Research, 18(3): 355-376. 
Seng, O. C. 2005. State-civil society relations and tourism: Singaporeanizing tourists, touristifying Singapore. Sojourn: journal of social issues in Southeast Asia, 20(2), 249272.

SGS Economics and Planning 2014. Australian cities accounts 2012-13. Available from: http://www.sgsep.com.au/assets/GDP-by-Major-Capital-City-1213-.pdf [Accessed 26 April 2016].

SGS Economics and Planning. 2017. Australian Cities Accounts 2015-16. Avaiłablefrom: https://www.sgsep.com.au/application/files/9914/8106/1313/GDP majo capidal_ci ty_201516_-_high_res.pdf [Accessed12 March 2017].

Simpson, T. 2014. Macau metropolis and mental life: Interior urbanism and the Chinese imaginary. International Journal of Urban and Regional Research, 38(3): 823-842.

Sklair, L. 2010. Iconic architecture and the culture-ideology of consumerism. Theory, Culture and Society, 27(5): 135-159.

Sklair, L., and Gherardi, L. 2012. Iconic architecture as a hegemonic project of the transnational capitalist class. City $10(1-2), 57-73$.

SMH [Sydney Morning Herdl]. 2011. Petytion forces debate on Barangaroo. 4 May. Available from: tttp://y/ww.smh.com.au/nsw/petition-forces-debate-on-barangaroo20110504- e7ks. thl [Accessed 20 March 2017].

Stickelf, D. 2010. Barangaroo: Instant urbanism - just add water. Architecture Australia, $99(3): 47-51$.

Sussex, M and Penn, S. 2011. Barangaroo Review.

The Star (2016). Design excellence competition for proposed new tower at the Star Sydney [Media release]. Available from: https://development.star.com.au/sites/default/files/pdfs/MEDIA\%20RELEASE\%20- 
\%20The\%20Star\%20Announces\%20Design\%20Excellence\%20Competition.pdf

[Accessed 15 February 2017].

The Star. n.d.. The Star Sydney unveils winning design for proposed hotel tower. Available from: https://development.star.com.au/ [Accessed 15 February 2017].

UNLV Center for Gaming Research. 2016. Macau gaming summary. Available from:

February http://gaming.unlv.edu/abstract/macau.html [Accessed 15 February 2017].

Urban Studies Research Centre. 2000. Impact of the Sydney Casino on the Sociat

Composition and Residential Amenity of the Residents of Pyrmont Wimo: Final Report

to Casino Community Benefit Fund. Sydney: Urban Studies Researoh Centre,

University of Western Sydney.

Urry, J. and Larsen, J. 2011. The tourist gaze 3.0. Aondon: Sage.

Walker, M. B. 1998. Gambling government: The EConomy and Social Impacts. Sydney:

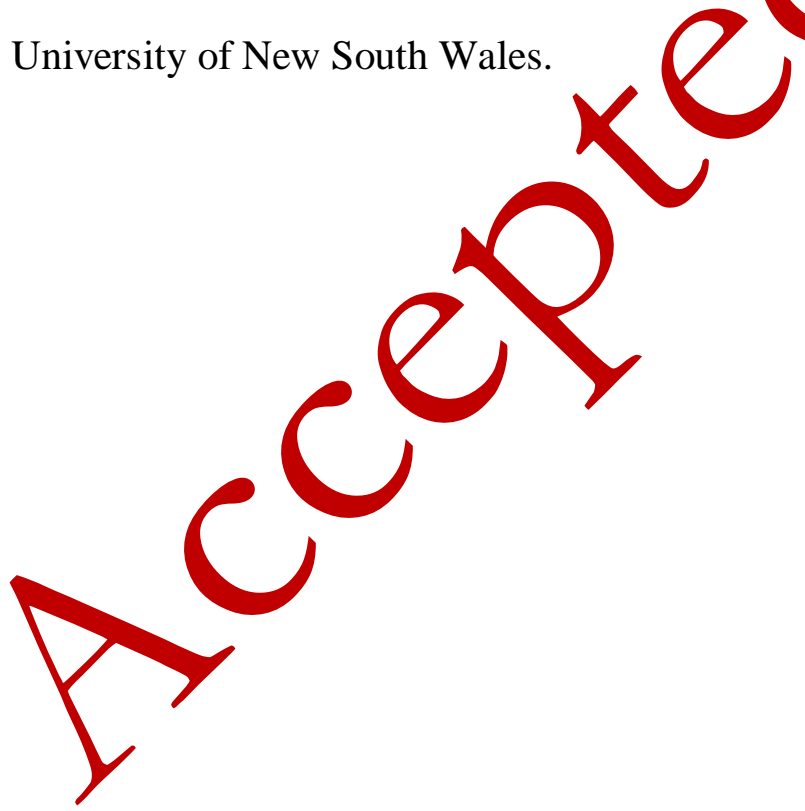

